Provided for non-commercial research and education use. Not for reproduction, distribution or commercial use.

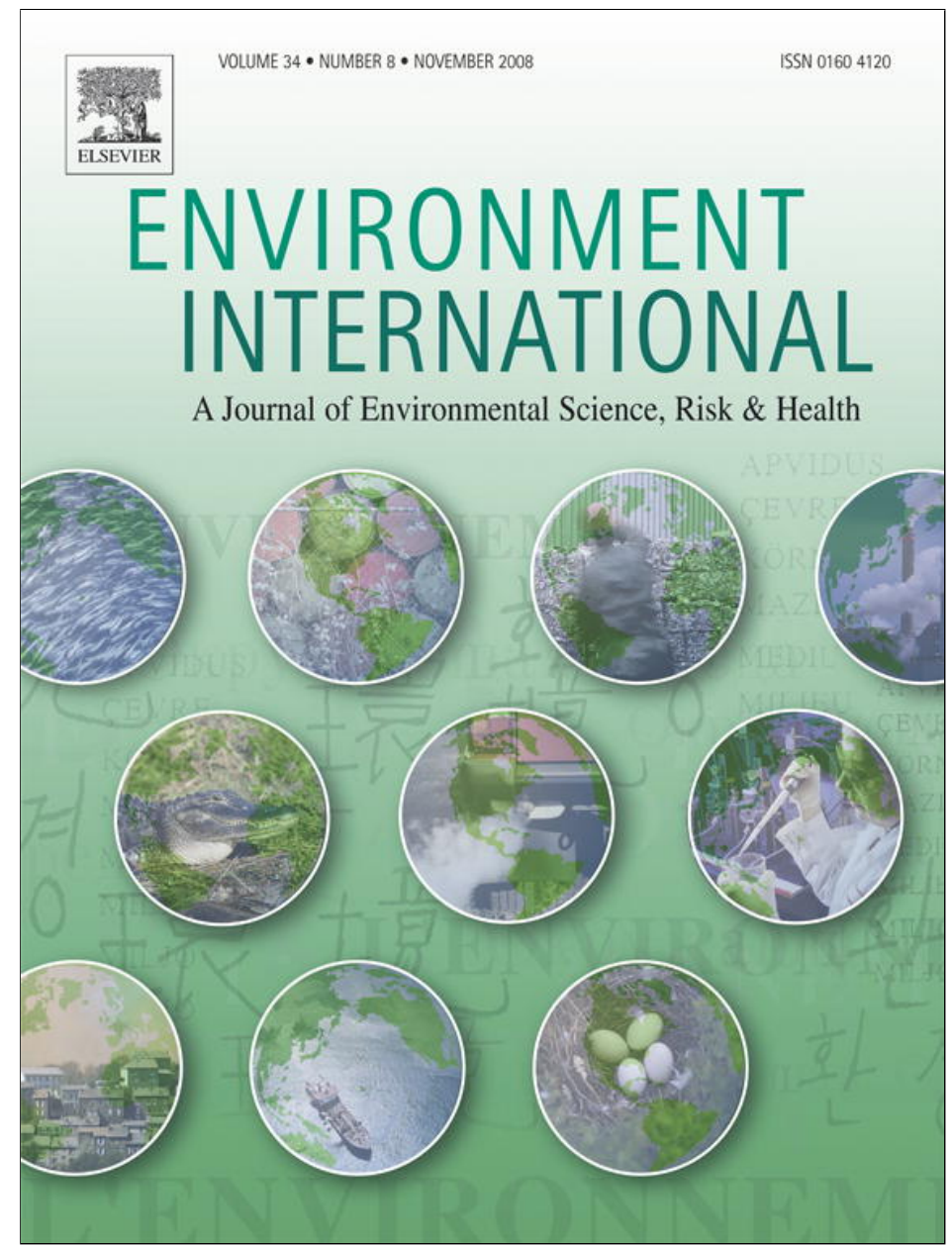

This article appeared in a journal published by Elsevier. The attached copy is furnished to the author for internal non-commercial research and education use, including for instruction at the authors institution and sharing with colleagues.

Other uses, including reproduction and distribution, or selling or licensing copies, or posting to personal, institutional or third party websites are prohibited.

In most cases authors are permitted to post their version of the article (e.g. in Word or Tex form) to their personal website or institutional repository. Authors requiring further information regarding Elsevier's archiving and manuscript policies are encouraged to visit:

http://www.elsevier.com/copyright 


\title{
Essential and non-essential trace metals in scalp hair of men chronically exposed to volcanogenic metals in the Azores, Portugal
}

\author{
André F.S. Amaral *, Mónica Arruda, Susana Cabral, Armindo S. Rodrigues \\ CIRN, Department of Biology, University of the Azores, APT 1422, 9501-855 Ponta Delgada, Portugal
}

\section{A R T I C L E I N F O}

\section{Article history:}

Received 5 January 2008

Accepted 31 March 2008

Available online 15 May 2008

\section{Keywords:}

Health

Volcanism

Biomarkers

Scalp hair

Cadmium

Copper

Lead

Rubidium

Selenium

Zinc

\begin{abstract}
A B S T R A C T
Volcanoes produce and release large amounts of toxicants, and the concentration of metals in hair can be used as a biomarker of exposure to trace metals. In order to investigate whether humans exposed to volcanic emissions demonstrate higher concentrations of essential and non-essential trace metals, scalp hair of men (3-89 years) living in two areas of the Azores, one exposed to volcanic emissions and the other not, was sampled, and their content in $\mathrm{Cd}, \mathrm{Cu}, \mathrm{Pb}, \mathrm{Rb}, \mathrm{Se}$, and $\mathrm{Zn}$ was quantified by using High Resolution Inductively Coupled Plasma Mass Spectrometry. In average, men exposed to volcanic emissions presented higher concentrations of Cd (96.9 ppb), Cu (16.2 ppm), Pb (3417.6 ppb), Rb (216.3 ppb), and Zn (242.8 ppm), but not Se (469.6 ppb). Also, strong and significant correlations were found between $\mathrm{Cd}-\mathrm{Rb}$ and $\mathrm{Pb}-\mathrm{Rb}$ in the exposed men. In conclusion, humans living chronically exposed to volcanic emissions show high concentrations of essential and non-essential trace metals in scalp hair, and is suggested that this type of exposure may be as harmful as living close to industrial facilities.
\end{abstract}

(c) 2008 Elsevier Ltd. All rights reserved.

\section{Introduction}

Metals are ubiquitous elements, being present in the environment and in all living organisms. Some metals are essential to life as they are involved in multiple functions, such as enzymes structure and activity, transport proteins, hormonal function and specific receptor sites, being crucial for the well functioning of the biological systems, if maintained at required levels (Apostoli, 2002). For example, $\mathrm{Zn}$ that is the most abundant intracellular component is involved in genetic stability and gene expression as well as in DNA repair and programmed cell death (Dreosti, 2001). Deficiency in Zn has been associated with growth retardation and increasing cancer risk, but in excess it can be neurotoxic (Cai et al., 2005; Dreosti, 2001). Cu is a component of various enzymes, is involved in collagen synthesis and in the normal development of connective tissues, nerves and immune system. In excess, Cu can be extremely toxic due to its pro-oxidant activity, causing DNA damage, and it has been associated with neurodegenerative changes such as Alzheimer's disease (Cai et al., 2005; Llanos and Mercer, 2002). Se is present in various enzymes,

Abbreviations: $\mathrm{Cd}$, cadmium; $\mathrm{Cu}$, copper; $\mathrm{Pb}$, lead; ppb, parts per billion; ppm, parts per million; Rb, rubidium; Se, selenium; S.E., standard error; Zn, zinc.

* Corresponding author. Tel.: +351 296650 102; fax: +351 296650100.

E-mail address: afsamaral@gmail.com (A.F.S. Amaral). which are responsible for cell protection against oxidative damage, and is considered indispensable for normal growth and development of mammals (Ventura et al., 2005). Other metals are not considered essential and their presence, even at very low doses, may result in impairment of biological functions (Apostoli, 2002). For instance, $\mathrm{Cd}$ is carcinogenic and $\mathrm{Pb}$ neurotoxic, and even in small amounts both may interact with calcium and replace it in the skeleton or $\mathrm{Zn}$ in the heme enzymes and metallothioneins (Goyer, 1997; Shukla et al., 1998; Waalkes, 2003).

$\mathrm{Rb}$ is a rarely studied but abundant alkali metal that competes with K for enzymatic sites (Meltzer, 1991) and that has been found in high levels in malignant and benign thyroid nodules (Zaichick et al., 1995). Though safe levels are not known, toxic responses linked to high concentrations of $\mathrm{Rb}$ have been found in mammals with high- $\mathrm{Rb}$ low$\mathrm{K}$ diets (Kosla et al., 2002).

The effects of environmental exposure to trace metals on human health have been discussed in the last decades, especially with respect to toxic metals originating in anthropogenic activities, but little has been said concerning natural pollution and especially volcanic activity. Volcanic emissions during eruptions and post-eruption periods may represent a significant risk to human health because of acute and/or chronic exposure to toxic gases and metals (Amaral et al., 2006a; Amaral and Rodrigues, 2007). Among others, $\mathrm{Cd}, \mathrm{Cu}, \mathrm{Pb}, \mathrm{Rb}$, and $\mathrm{Zn}$ are some of the metals emitted by volcanoes during and after the eruption (Delmelle and Stix, 2000; Durand et al., 2004). 
As metals are present in the air, soil, food and water, they enter the organism through skin, respiratory tract and digestive system, being the excess excreted through the sweat, hair, urine and faeces (Apostoli, 2002). Interest in the hair as a marker of basic levels of metals in the human body has recently increased due to some advantages over urine or blood, particularly because it is a metabolic end product that has a recognized ability to reflect the body metal burden. Moreover, the elemental composition of the hair reflects long-term exposure, while blood or urine represents a current, or acute, situation (Chojnacka et al., 2005). The concentration of a certain metal in hair reveals a balanced mineral content of the individual body pool over a long period of time, which can only be significantly modified by exposure or intake of high quantities of trace metals. Thus, the quantification of trace elements in hair has been used as a biomarker enabling the assessment of both long-term environmental exposure to trace metals and metabolic status concerning chronic nutritional deficiencies (Hopps, 1977; Khalique et al., 2005; Rivai, 2001).

The objective of this study was to compare the concentrations of $\mathrm{Cd}$, $\mathrm{Cu}, \mathrm{Pb}, \mathrm{Rb}, \mathrm{Se}$, and $\mathrm{Zn}$ in scalp hair of men from two rural areas in the Azores distinguishable by the occurrence of volcanic activity. In one area (Furnas) volcanic activity is present as hydrothermal waters, degassing soils and fumaroles, while in the other area (St. Maria) there is no volcanic activity since 3 million years ago.

\section{Materials and methods}

\subsection{Study population}

The Azores is an archipelago of nine volcanic island located in the North Atlantic Ocean. Presenting fumarolic fields and hydrothermal vents (Booth et al., 1978; Cruz, 2003), and the always present "rotten egg" odor, the rural village of Furnas, in S. Migue Island, is built upon actively degassing ground inside a volcanic caldera (Baxter et al. 1999), where the last eruption occurred at $1630 \mathrm{AD}$ (Cole et al., 1995). This village has about 1541 inhabitants (Serviço Regional de Estatística dos Açores, 2003), where the age groups $0-14,15-24,25-44,45-64$, and over 64 represent $22 \%, 16 \%, 27 \%, 19 \%$, and $16 \%$ of the local population, respectively. Santa Maria, which is one of the smallest islands $\left(92 \mathrm{~km}^{2}\right.$ ), has about 5578 inhabitants (Serviço Regional de Estatística dos Açores, 2003), and is also rural but, in contrast, has had no volcanic activity since 3 million years ago (Feraud et al., 1984). In Santa Maria, the age groups 0-14, 15-24, 25-44, 45-64, and over 64 represent $24 \%, 16 \%, 30 \%, 18 \%$, and $12 \%$ of the local population, respectively. Both populations are similar in access to medical care, socioeconomic status, economy, and home construction, but dissimilar in terms of smoking, where Furnas and Santa Maria differ since they present $25 \%$ and $44 \%$ prevalence, respectively (Peixoto, 2005).

\subsection{Hair sampling and analysis}

Samples of scalp hair of 158 men aged 3-89 were obtained from Furnas $(n=68)$ and Santa Maria $(n=90)$, but only from those who did not have dyed or treated hair. Previous to sample collection, all participants or legal representatives signed an informed consent authorizing it. Also, tobacco smoking habit of each donor was recorded. Those who smoked one or more cigarettes per day were considered smokers.

Cu

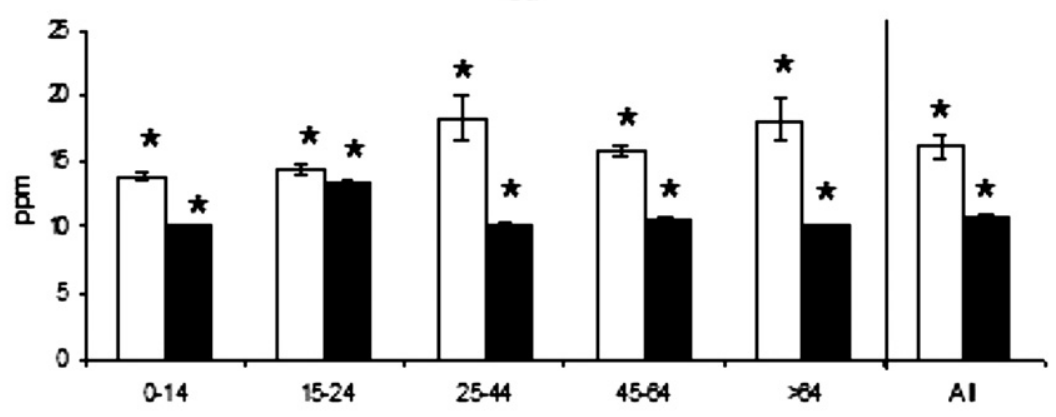

Se

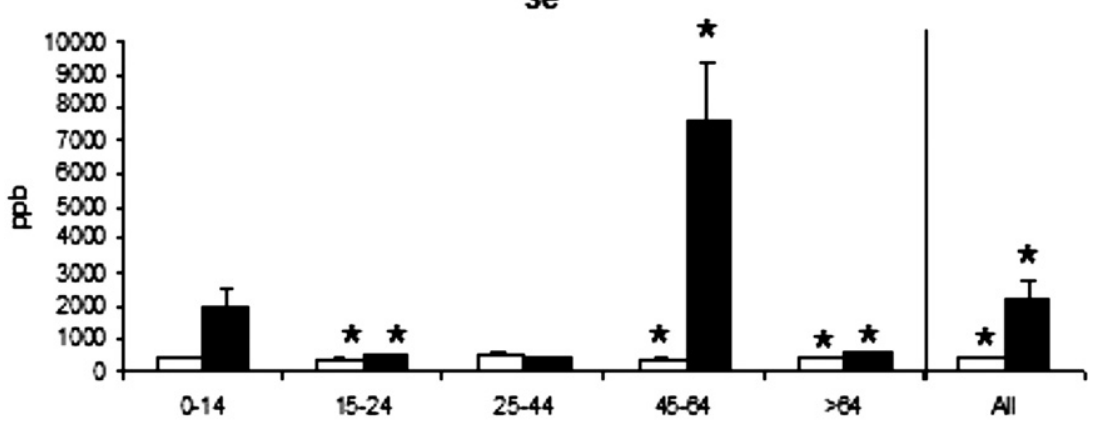

Zn

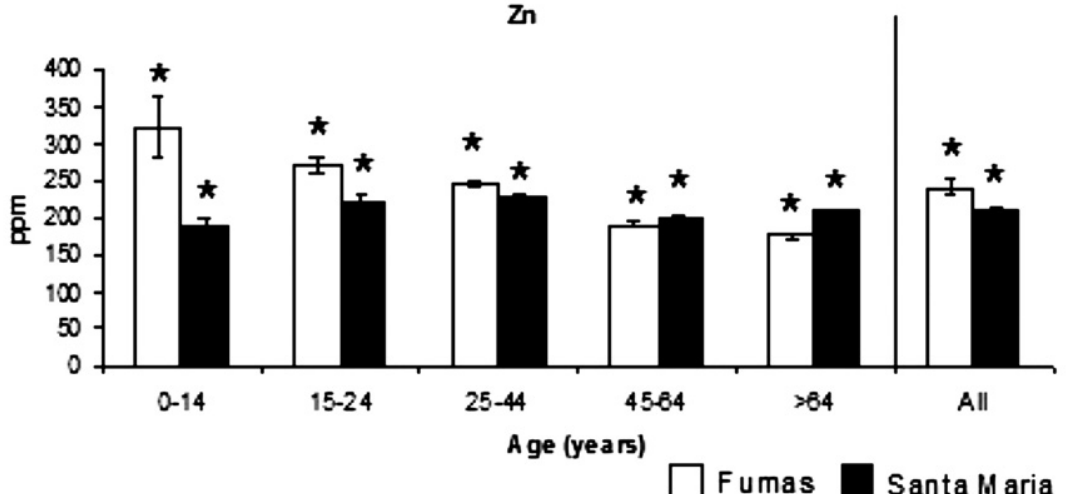

Fig. 1. Mean concentrations ( \pm S.E.) of copper (Cu), selenium (Se) and zinc $(\mathrm{Zn})$ in hair samples of men from Furnas and Santa Maria. Asterisks indicate significant differences ( $p \leq 0.05)$ between sites for each age group. 
Cd

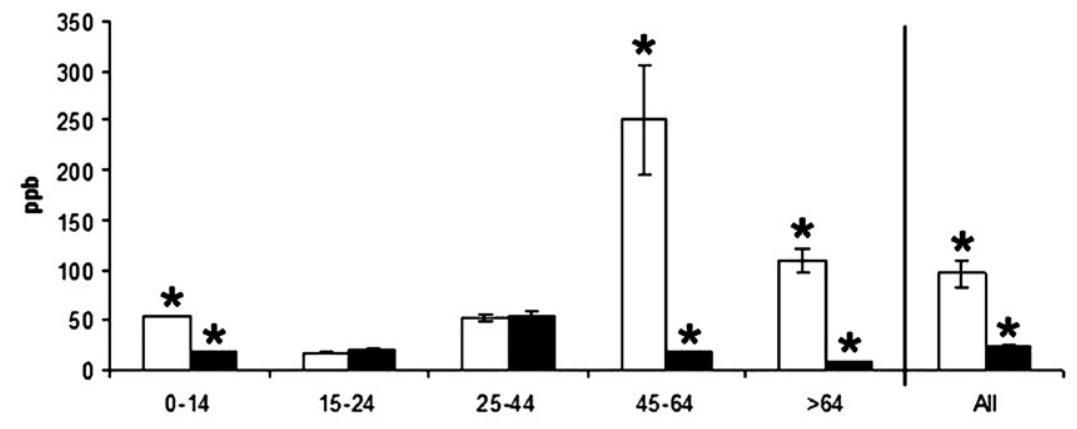

$\mathrm{Pb}$

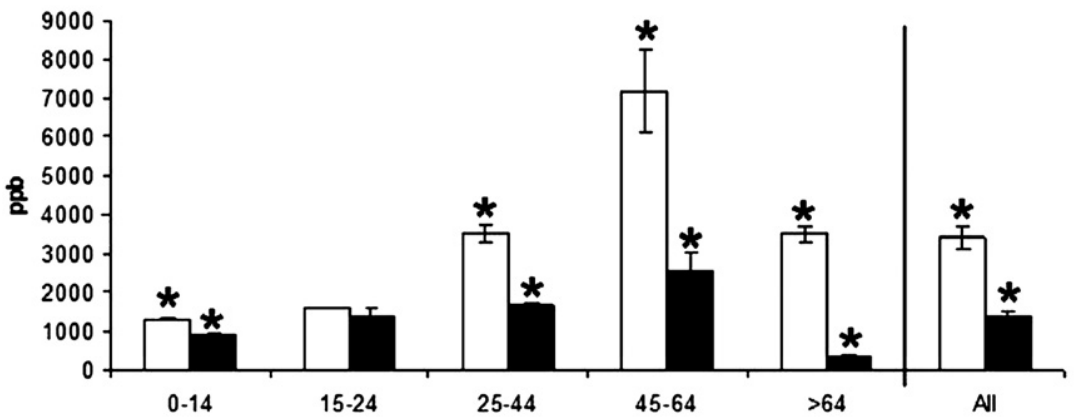

$\mathbf{R b}$

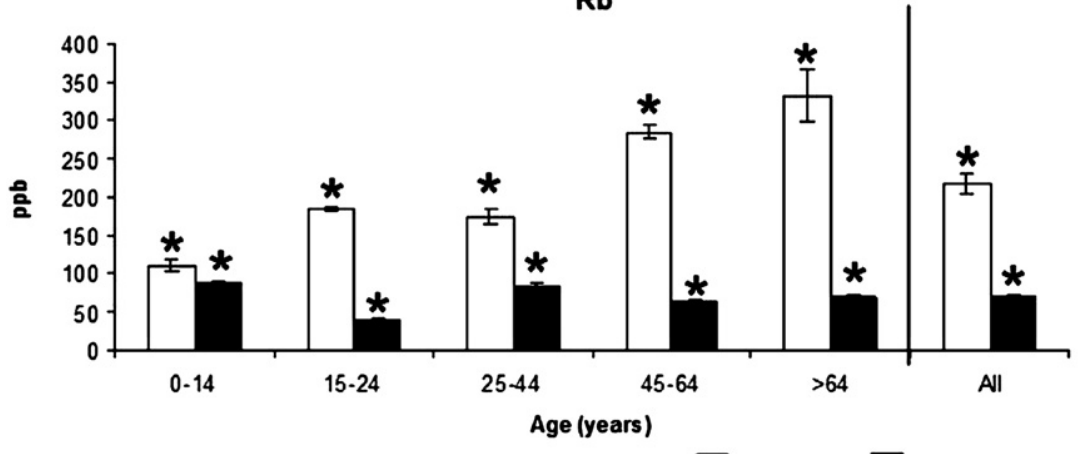

Furnas Santa Maria

Fig. 2. Mean concentrations $( \pm$ S.E.) of cadmium $(\mathrm{Cd})$, lead $(\mathrm{Pb})$, and rubidium $(\mathrm{Rb})$ in scalp hair of men from Furnas and St. Maria. Asterisks over the bars indicate significant differences at $p \leq 0.05$.

In order to eliminate external contamination, each hair sample was washed in a sequence of acetone, bi-distilled water, and acetone (Ryabukkin, 1978). After washing, each sample was air-dried at room temperature in a dust-free area. Then they were digested in aqua regia at $95^{\circ} \mathrm{C}$, for $2 \mathrm{~h}$, and with microwave inside a closed Teflon vessel, for $45 \mathrm{~min}$ and $1 \mathrm{~h}$ plus. Prior to analysis samples were always kept away from metallic materials and dust to avoid contamination. For analysis of $\mathrm{Cd}, \mathrm{Cu}, \mathrm{Pb}, \mathrm{Rb}, \mathrm{Se}$, and $\mathrm{Zn}$, the resultant sample solutions were diluted and analyzed on a Finnegan Mat Element 2 High Resolution ICP/MS For quality control, internal standards and reference materials were run together with the samples. At least, six different reference materials covering all the elements in the study were used. Duplicate samples were also used in order to determine precision of the analysis. For each element, a minimum of three standards were used to cover the analytical working range of the instrument. Ultrapure water was used to prepare calibration standards and blanks, and three replicate determinations were performed for each sample.

\subsection{Statistical analysis}

Differences in metal concentrations in hair between groups were examined using the Mann-Whitney $U$ test and considered significant when $p \leq 0.05$. Also, the Spearman's correlations between all analyzed metals found in hair were assessed. To perform this statistical analysis the SPSS 14.0 (SPSS Inc.) was used.

\section{Results}

In general, hair of men from Furnas (with volcanic activity) presented significantly high concentrations of all trace metals, with the exception of Se (Figs. 1 and 2), when compared to that of men from Santa Maria (without such activity).
While the concentrations of $\mathrm{Cu}$ and $\mathrm{Zn}$ were stable along the different age groups in Santa Maria, in Furnas they showed different behaviors with $\mathrm{Cu}$ increasing and $\mathrm{Zn}$ decreasing with increasing age, respectively (Fig. 1). The concentrations of $\mathrm{Cd}$, and especially $\mathrm{Pb}$ and $\mathrm{Rb}$ in hair of men from Furnas showed a pattern of increase along with age (Fig. 2). On the other hand, Se concentrations were higher in hair of men from Santa Maria, when compared to that of men from Furnas (Fig. 1).

Concerning the six trace metals, in neither sites we found significant differences between smokers and non-smokers, except for the group of 45-64 years. Among smokers, we found that men from Furnas presented significantly (Mann-Whitney $U$, $p<0.05$ ) high concentrations of all trace metals when compared to those from Santa Maria. Among non-smokers, we did not find a pattern transversal to all age groups, but we found that children ( $0-14$ years) from Furnas presented higher (Mann-Whitney $U$, $p<0.05$ ) concentrations of all trace metals, except Se, than those from Santa Maria.

Table 1

Spearman's correlations coefficients between all six trace metals

\begin{tabular}{lllllll}
\hline & $\mathrm{Cd}$ & $\mathrm{Cu}$ & $\mathrm{Pb}$ & $\mathrm{Rb}$ & $\mathrm{Se}$ & $\mathrm{Zn}$ \\
\hline $\mathrm{Cd}$ & - & & & & & \\
$\mathrm{Cu}$ & $0.357^{* *}$ & - & & & & \\
$\mathrm{Pb}$ & $0.698^{* *}$ & $0.571^{* *}$ & - & & & \\
$\mathrm{Rb}$ & $0.648^{* *}$ & $0.558^{* *}$ & $0.570^{* *}$ & - & & \\
$\mathrm{Se}$ & $-0.188^{*}$ & $-0.295^{* *}$ & -0.049 & $-0.323^{* *}$ & - & \\
$\mathrm{Zn}$ & -0.069 & $0.286^{* *}$ & -0.040 & 0.016 & -0.081 & - \\
\hline
\end{tabular}

${ }^{* *}$ Correlation is significant at $p \leq 0.01$. ${ }^{*}$ Correlation is significant at $p \leq 0.05$. 
In average, we found strong and significant correlations between $\mathrm{Rb}$ and $\mathrm{Cd}, \mathrm{Cu}$, and $\mathrm{Pb}$, as well as between $\mathrm{Pb}$ and $\mathrm{Cd}$, and $\mathrm{Cu}$ (Table 1).

\section{Discussion}

In general, concentrations of $\mathrm{Cd}, \mathrm{Cu}, \mathrm{Pb}, \mathrm{Rb}$, and $\mathrm{Zn}$ were higher in the scalp hair of men from Furnas. According to age, the highest levels of these metals were found in the oldest groups, which may indicate a possible bioaccumulation effect through aging. $\mathrm{Cd}$ and $\mathrm{Pb}$ levels in men of both areas were lower than those from developing countries (Khalique et al., 2005; Rivai, 2001; Sharma and Kumar, 2005) and the surrounding area of an abandoned mine in Portugal mainland (Pereira et al., 2004), but in contrast the concentrations in men from Furnas were higher than those of developed countries, such as Germany, Italy or Canada (Goullé et al., 2005; Seifert et al., 2000; Violante et al., 2000). These differences between countries may be due to different types of industries and also to the late banning of leaded gasoline in the developing countries. Men from Furnas present $\mathrm{Cd}$ and $\mathrm{Pb}$ concentrations in-between developing and developed countries most likely because of the volcanic input, which sets this area to a moderately polluted area, and less likely because of smoking habits.

The concentrations of $\mathrm{Rb}$ in men from Furnas were not only higher than the levels of men from St. Maria, but also extremely higher than levels found in Canadian men (Goullé et al., 2005). Although Rb is not considered extremely toxic it can exert toxic effects when in high concentrations, mainly because it competes with $\mathrm{K}$ for enzymes, such as the $\mathrm{Na}^{+} / \mathrm{K}^{+}$-ATPase (Meltzer, 1991; Mitchell et al., 1921). Accumulation of $\mathrm{Rb}$ has been observed in several organs of rats, and reported effects of this accumulation include spasms and tissue disorganization (Mitchell et al., 1921; Salaün and Truchet, 1996). Strong and significant correlations found in donors from Furnas between $\mathrm{Rb}-\mathrm{Cd}$ and $\mathrm{Rb}-\mathrm{Pb}$ show that $\mathrm{Rb}$ hair concentrations may be used as biomarker of exposure to volcanic emissions, composed of more harmful gases and aerosols, as previously suggested by Durand et al. (2004).

In the case of $\mathrm{Cu}$, the concentrations found were almost always below the reference levels, being particularly low in scalp hair of men from Santa Maria (Fig. 1).

Concentrations of $\mathrm{Zn}$ were always above the maximum reference level, being higher in men from Furnas, particularly in scalp hair of children where it reaches a maximum of 321 ppm (Fig. 1).

Hair of men from Furnas showed lower concentrations of Se than that of men from Santa Maria, but nevertheless men from the latter presented concentrations below reference levels, with the exception of age groups 0-14 and 45-64 (Bleise et al., 2000; Goullé et al., 2005). Values observed in these two age groups may be due to high concentrations of Se in very few individuals, probably as a consequence of dietary supplements or any chemical medication used as cancer chemopreventive agent, not assessed in this study, which may explain the high standard errors. The low Se concentrations detected in men from Furnas were in accordance to data referred by Pavão et al. (2003) that, comparing a group of people from this site with a group of people from a fishing community, concluded blood Se levels were lower in the individuals living in Furnas.

According to the present results, it seems that the concentrations found in the hair of men from Furnas and from Santa Maria were more influenced by the exposure to volcanic emissions than to tobacco smoking. Although it is known that smokers usually tend to present higher levels of trace metals, such as Cd, than non-smokers, the lack of significant differences between them, in most age groups, in hair metal concentrations strengthens the former hypothesis.

Previous studies in Furnas showed that: (i) soil invertebrates and mice present high levels of trace metals, such as Cd and Zn (Amaral et al., 2006b, 2007); and (ii) humans present high incidence of chronic bronchitis and some cancer types, which may be related to volcanic emissions (Amaral et al., 2006a; Amaral and Rodrigues, 2007). Since the cancer chemopreventive role of Se has been well documented
(Brinkman et al., 2006; Kellen et al., 2006), it is reasonable to speculate as to a possible association between the low concentrations of this element, the high concentrations of $\mathrm{Cd}$, which is carcinogen, and $\mathrm{Pb}$, which is a probable carcinogen, and some of the cancers found previously. Although further studies should be performed to better understand the possible associations between chronic exposure to volcanogenic pollutants and health outputs, our present and previous results suggest that living chronically exposed to volcanic emissions may be as harmful as living close to industrial facilities.

\section{Acknowledgements}

This study was financially supported by CIRN (University of the Azores), and DRCT (Government of the Azores). André F. S. Amaral was supported by a Postdoctoral grant from FCT (SFRH/BPD/27136/2006).

\section{References}

Amaral AF, Cabral C, Guedes C, Rodrigues AS. Apoptosis, metallothionein, and bioavailable metals in domestic mice (Mus musculus L.) from a human-inhabited volcanic area. Ecotoxicology 2007;16:475-82.

Amaral AFS, Rodrigues AS. Chronic exposure to volcanic environments and chronic bronchitis incidence in the Azores, Portugal. Environ Res 2007;103:419-23.

Amaral A, Rodrigues V, Oliveira J, Pinto C, Carneiro V, Sanbento R, et al. Chronic exposure to volcanic environments and cancer incidence in the Azores, Portugal. Sci Total Environ 2006a;367:123-8.

Amaral A, Soto M, Cunha RMPTT, Marigómez I, Rodrigues AS. Bioavailability and cellular effects of metals on Lumbricus terrestris inhabiting volcanic soils. Environ Pollut 2006b;142:103-8.

Apostoli P. Elements in environmental and occupational medicine. J Chromatogr B 2002;778:63-97.

Baxter PJ, Baubron JC, Coutinho R. Health hazards and disaster potential of ground gas emissions at Furnas volcano, São Miguel, Azores. J Volcanol Geotherm Res 1999;92:95-106.

Bleise AR, Heller-Zeisler SF, Parr RM. Methylmercury, total mercury and other trace elements in human hair. Reference sheet. International Atomic Energy Agency; 2000.

Booth B, Croasdale R, Walker GPL. A quantitative study of five thousand years of volcanism on São Miguel, Azores. Philos Trans R Soc Lond A 1978;288:271-319.

Brinkman M, Buntinx F, Muls E, Zeegers MP. Use of selenium in chemoprevention of bladder cancer. Lancet Oncol 2006;7:766-74.

Cai L, Li X, Song Y, Cherian MG. Essentiality, toxicology and chelation therapy of zinc and copper. Curr Med Chem 2005;12:2753-63.

Chojnacka K, Górecka H, Chojnacki A, Górecki H. Inter-element interactions in human hair. Environ Toxicol Pharmacol 2005;20:368-74.

Cole PD, Queiroz G, Wallenstein N, Gaspar JL, Duncan AM, Guest JE. An historic subplinian/phreatomagmatic eruption: the $1630 \mathrm{AD}$ eruption of Furnas volcano, São Miguel, Azores. J Volcanol Geotherm Res 1995;69:117-35.

Cruz JV. Groundwater and volcanoes: examples from the Azores archipelago. Environ Geol 2003:44:343-55.

Delmelle P, Stix J. Volcanic gases. In: Sigurdsson H, Houghton BF, McNutt SR, Rymer H, Stix J, editors. Encyclopedia of volcanoes. San Diego: Academic Press; 2000. p. $803-16$.

Dreosti IE. Zinc and the gene. Mutat Res-Rev Mutat 2001:475:161-7.

Durand M, Florkowski C, George P, Walmsley T, Weinstein P, Cole J. Elevated trace element output in urine following acute volcanic gas exposure. J Volcanol Geoth Res 2004;134:139-48.

Feraud G, Schinke HU, Lietz J, Gostaud J, Pritchard G, Bleil U. New K-Ar ages, chemical analyses and magnetic data of rocks from the islands of Santa Maria (Azores), Porto Santo and Madeira (Madeira archipelago) and Gran Canaria (Canary islands). Arquipél Ciênc Nat 1984;5:213-40.

Goullé JP, Mahieu L, Castermant J, Neveu N, Bonneau L, Lainé G, et al. Metal and metalloid multi-elementary ICP-MS validation in whole blood, plasma, urine and hair. Reference values. Forensic Sci Int 2005;153:39-44.

Goyer RA. Toxic and essential metal interactions. Annu Rev Nutr 1997;17:37-50.

Hopps HC. The biologic bases for using hair and nail for analyses of trace elements. Sci Total Environ 1977;7:71-89.

Kellen E, Zeegers M, Buntinx F. Selenium is inversely associated with bladder cancer risk: a report from the Belgian case-control study on bladder cancer. Int J Urol 2006;13:1180-4

Khalique A, Shah MH, Jaffar M, Shaheen N, Manzoor S, Tariq SR. Status of selected heavy metal distribution in scalp hair of traffic control personnel exposed to vehicular emissions. Hum Ecol Risk Assess 2005;11:1065-75.

Kosla T, Skibniewska E, Debski B, Urbanska-Slomka G. Rubidium in the trophic chain soil-plants-animals. Trace Elem Electroly 2002;19:171-6.

Llanos RM, Mercer JFB. The molecular basis of copper homeostasis and copper-related disorders. DNA Cell Biol 2002;21:259-70.

Meltzer HL. A pharmacokinetic analysis of long-term administration of rubidium chloride. J Clin Pharmacol 1991;31:179-84.

Mitchell PH, Wilson JW, Stanton RE. The selective absorption of potassium by animal cells: II. The cause of potassium selection as indicated by the absorption of rubidium and cesium. J Gen Physiol 1921;4:141-8. 
Pavão ML, Cordeiro C, Costa A, Raposo JA, Santos MC, Neve J, et al. Comparison of wholeblood glutathione peroxidase activity, levels of serum selenium, and lipid peroxidation in subjects from the fishing and rural communities of "Rabo de Peixe" Village, San Miguel Island, The Azores' Archipelago, Portugal. Biol Trace Elem Res 2003;92:27-40.

Peixoto A. Dependências e Outras Violências...Perspectiva Taxológica. Ponta Delgada: DRJEFP/CRA-PSP; 2005

Pereira R, Ribeiro R, Gonçalves F. Scalp hair analysis as a tool in assessing human exposure to heavy metals (S. Domingos mine, Portugal). Sci Total Environ 2004;327:81-92.

Rivai IF. Heavy metals in human hair related to age groups and automotive pollution levels of Bandarlampung City, Indonesia. Bull Environ Contam Toxicol 2001;66:443-8.

Ryabukkin YS. Activation analysis of hair as an indicator of contamination of man by environmental trace element pollutants. Vienna: IAEA; 1978.

Salaün ML, Truchet M. Étude, par émission ionique secondaire, de l'accumulation du rubidium dans les tissus mous de l'huître Crassostrea gigas (Mollusque, Lamellibranche). Cah Biol Mar 1996;37:329-40.

Seifert B, Becker K, Helm D, Krause C, Schulz C, Seiwert M. The German Environmental Survey 1990/1992 (GerES II): reference concentrations of selected environmental pollutants in blood, urine, hair, house dust, drinking water and indoor air. J Expo Anal Env Epid 2000;10:552-65.

Serviço Regional de Estatística dos Açores. Censos 2001: Principais Resultados Definitivos dos Censos 1991 e 2001. Angra do Heroísmo: SREA; 2003.

Sharma R, Kumar A. Human head hair as a tool in environmental pollution monitoring of Agra City. Bull Environ Contam Toxicol 2005;74:415-20.

Shukla VK, Prakash A, Tripathi BD, Reddy DCS, Singh S. Biliary heavy metal concentrations in carcinoma of the gall bladder: case-control study. Br Med J 1998;317:1288-9.

Ventura MG, Freitas MC, Pacheco AMG. Selenium levels in mainland Portugal. Water Air Soil Pollut 2005;166:167-79.

Violante N, Senofonte O, Marsili G, Meli P, Soggiu ME, Caroli S. Human hair as a marker of pollution by chemical elements emitted by a thermoelectric power plant. Microchem J 2000;67:397-405.

Waalkes MP. Cadmium carcinogenesis. Mut Res 2003:533:107-20.

Zaichick VY, Tsyb AF, Vtyurin BM. Trace elements and thyroid cancer. Analyst $1995 ; 120: 817-21$. 